\title{
Determinants of Excursionists' Satisfaction and Loyalty Towards Architectural Tourism in Ipoh Township, Malaysia
}

\author{
Anna Manisha Rames' ${ }^{1}$, Tan Gek Siang1, Yeo Sook Fern ${ }^{1}$ \\ ${ }^{1}$ Faculty of Business, Multimedia University, Melaka, Malaysia
}

\begin{abstract}
This study examines the determinants of excursionists' satisfaction and destination loyalty towards architectural tourism destination in Ipoh Township, since in view of its economic, social and cultural importance, there are limited studies focusing on tourist satisfaction and destination loyalty towards architectural tourism in the extant literature. In addition, the downturn of the tourism sector in Malaysia has mirrored in the state of Perak which raises an alarming signal to the state tourism authorities as domestic tourists are shifting away to tourism destinations in other states and cities in Malaysia. It is postulated that Destination Image, Authenticity, Safety of Destination and Cultural Differences as direct determinants of excursionists' satisfaction and destination loyalty. Using convenience sampling technique, this study surveyed 250 excursionists who are visiting architectural tourism destination in Ipoh Township. The data were analysed to ensure the attainment of internal reliability before further analyses were conducted. Multiple linear regression analyses found that all determinants had a significant positive effect on excursionists' satisfaction and destination loyalty. The findings suggest managerial implications to the tourism stakeholders in preserving the heritage and cultural value of the Ipoh Township. Limitations and suggestions for future research are also highlighted.
\end{abstract}

Keywords: Architectural Tourism; Satisfaction; Destination Loyalty; Malaysia

This is an open access article under the CC-BY-NC license.

\section{INTRODUCTION}

The term architecture does not have a specified definition due to the lack of consensus and varying opinions by the extant researchers. However, architecture can be referred as an expertise and science of designing buildings. Also, architecture is an enduring existence that shapes our surrounding and forms a destination image in the mind of both citizens and visitors. While tourism involves people travel from their original setting to a tourist destination, architectural tourism is an act of going by dated residence such as a standard structure or an antique house for witnessing and embracing the architecture (Lee, Jiun, Kuo \& Muhos, 2015). In simpler terms, architectural tourism involves people travel to a tourist destination to visit historical monuments and architectural buildings. The association between architecture and tourism is clear as both have an imperative part by becoming a fascination for tourists.

Corresponding author Anna Manisha Rames, anna_manisha@yahoo.com; Tan Gek Siang, gstan@mmu.edu.my; Yeo Sook Fern, yeo.sook.fern@mmu.edu.my 
Tourism and Sustainable Development Review Journal (TSDR), Vol. 2 (1), 01-18 Determinants of Excursionists' Satisfaction and Loyalty Towards Architectural Tourism in Ipoh Township, Malaysia

Anna Manisha Rames, Tan Gek Siang, Yeo Sook Fern

Most cities and townships have a mixture of old and new buildings. The design of long established architectures in Malaysia have a strong cultural influence of the Malay, Chinese, Indian, Sarawak and Sabah, as well as colonial styles of the Dutch, Portuguese and British. In contrast, modern architectures such as the Merdeka PNB118, The Exchange 106, the Petronas Twin Towers and the KL Tower exhibit the evolution of architectures in Malaysia. Credit to the unique blend of old and contemporary buildings, architectural tourism is now one of the noteworthy branches of tourism in Malaysia that visitors are enthusiastic about. The World Tourism Organisation (2019) reported that Malaysia is currently ranked 15th in international tourist arrivals and 21st in international tourism receipts. Nevertheless, Malaysia failed to maintain its position as the top ten most visited countries worldwide since 2013 and overtook by Thailand as the most visited Southeast Asian country since 2015 while Thailand and Singapore replaced Malaysia as the Southeast Asian country with the highest tourism revenue (World Tourism Organisation, 2019).

Our study interest is located by the Kinta River: Ipoh - the capital city of the state of Perak, is one of the largest cities in Malaysia with rich cultural heritage values. In the late 1870s, the British colonisation and exploitation of the tin industry had transformed the Malay villages into a thriving mining town which saw a mushrooming of colonial buildings left by the colonisers and wealthy traders. Being a colonial centre means Ipoh was a melting pot of numerous cultures that were brought by the colonisers and traders, leaving abundance of heritage assets in Ipoh. The township has quintessential and pre - war architectures that were previously built by the colonisers and used as government administration offices which are now becoming historical landmarks and architectural tourism destinations most sought-after by domestic and international tourists. However, the downturn of the tourism performance in Malaysia has mirrored at the state level when domestic tourists in Perak contracted by $12.72 \%$ in 2018 despite other states and cities in Malaysia recorded a positive growth (Department of Statistics Malaysia, 2019). The scenario raises an alarming signal to the state tourism authorities as domestic tourists are shifting away from Perak to other tourism destinations in other states and cities in Malaysia.

The attestation on mutual correlation that connects architecture and tourism are very little. Hence, extant studies that relate to visitors' satisfaction and destination loyalty are exceptionally slender in the context of architectural tourism. In terms of the research framework, this study aims to examine the determinants of excursionists' satisfaction and destination loyalty toward architectural tourism destination in Ipoh Township. An excursionist can be anyone who leaves his or her residence to visit a tourist destination and less than 24 hours.

\section{LITERATURE REVIEW}

Despite that architectural tourism destination allures the visitors, most townships still have problems in forming a well - defined selling proposition that promotes its destination image (Souiden, Ladhari \& Chiadmi, 2017) since the attitude and behaviour of the visitors are arduous to be forecasted and evaluated. Thus, generating effective motivation to travel and encouraging emotional image among the visitors can be challenging (Jamaludin, Johari, Aziz, Kayat \& Yusof, 2012). According to Albaity \& Melhem (2017), the relationship between destination image, satisfaction and destination loyalty has only been studied by very few researchers. As a consequence, visitors' motivation is an intricated area of exploration in psychological theories content (Albayrak \& Caber, 2018). Furthermore, there are no specific studies conducted to observe 
Tourism and Sustainable Development Review Journal (TSDR), Vol. 2 (1), 01-18

Determinants of Excursionists' Satisfaction and Loyalty Towards Architectural Tourism in Ipoh Township, Malaysia

Anna Manisha Rames, Tan Gek Siang, Yeo Sook Fern

the differences with destination loyalty to a single destination and numerous destinations at one time (Almeida - Santana \& Moreno - Gil, 2018), added with the influence of various factors on travel satisfaction make the viewpoint to be rather complex that it is yet to be completely understood by the researchers (Khuong \& Nguyen, 2017), which generally results in lesser studies conducted to study on destination loyalty (Almeida - Santana \& Moreno - Gil, 2017). Literature has accentuated concepts and definitions related to excursionists' satisfaction and destination loyalty toward architectural tourism destination which discusses on several variables as follows:

\section{Destination Image (DI)}

Destination image can be explained as a set of expectation, impression and the impact generated by an excursionist (Lu, Chi \& Liu, 2015) or as the amount of detailed, presuppose and informational belief that he or she has on a specific tourist destination (Souiden et al., 2017). Destination image is a cognitive perception which is formed by an excursionist throughout several sources of information (Jamaludin et al., 2012) by which the image reflects on his or her perception of how a tourist destination is built in his or her mind (Stylos, Bellou, Andronikidis \& Vassiliadis, 2017). The creation of image is developed from symbolic products, national features, economic, political, culture and history (Souiden et al., 2017). Certainly, image is created when the overlapping concept of "tourist destination image" and "product - country image" evolves separately (Souiden et al., 2017). Past researchers have also discussed on the elements which are considered in a destination by an excursionist which are convenience, richness of culture, impressive resources, security, enjoyment and night life, as well as the proportion of price and quality (RamseookMunhurrun, Seebaluck \& Naidoo, 2014).

Gartner (1993) developed the traits built in conceptualisation of the image of a tourist destination consist of cognitive, affective and conative segments. Cognitive view of a tourist destination entails the beliefs and associated facts, that mirrors the excursionist's evaluation of the perceived characteristics of the tourist destination; affective image reflects feeling, response or evaluation of an excursionist on the tourist destination; conative image explains the excursionist's active discussion of a place of promising tourist destination that sketches the approaching state the excursionist wants to perform (Stylos et al., 2017).

As it happens, the overall image of a tourist destination is different for an excursionist who is visiting for the first time compared to an excursionist who is repeating the visit (Abdullah \& Lui, 2018). Furthermore, international events and broadcasting media are also important factors in contributing and influencing the image of a tourist destination (Souiden et al., 2017). It is the responsibility of businesses to promote their townships and well-known tourism spots in their countries to increase excursionist's destination image (Frangos, Karapistolis, Stalidis, Constantinos, Sotiropoulos \& Manolopoulos, 2015). This is because it is important to attract more excursionists since a destination with a solid and positive image is much more preferable (Stylos et al., 2017). The previous studies have also confirmed that the relationship between destination image and satisfaction is significantly positive and has a direct relationship with intention to revisit (Albaity \& Melhem, 2017; Loi, So, Lo \& Fong, 2017; Ramseook-Munhurrun, Seebaluck \& Naidoo, 2014). Thus, it is hypothesised that destination image has a significant positive effect on satisfaction and destination loyalty. 


\section{Authenticity (AT)}

The anticipation of authenticity was inceptively advanced by Trilling (1999), for the purpose of museums, and eventually was widen in the coming years to cater for tourism to speak about customs and heritage as well as reviewing a sense of validity, aberrant and genuineness (Nguyen \& Cheung, 2015). The definition of authenticity was also later altered from the field of heritage and upkeep that reflects on the value of a site (Swanson \& DeVereaux, 2017). Belonging naturally at a place is regarded as authenticity, likewise perception or an excursionist's experience also proposes authenticity (Nguyen and Cheung, 2015). Authenticity is supplemented as the origination that can be used as emotions and knowledge (Yi, Fu \& Jiang, 2018).

There are numerous classifications for authenticity such as constructive, existential, symbolic, natural, original, referential, influential, stages and, cool and hot (Shen, Guo \& Wu, 2014; Thyne \& Hede, 2016). The most common classification of authenticity that has been mentioned in past researches are cool and hot, whereby the cool authenticity is fixed according to customary rules, criticism or knowledge of expert as of object - based authenticity; hot authenticity is constantly varying, allied to the exploration on an authentic self and others using constitutive technique (Yi et al., 2018). Architectural inheritance relies on original structure, decorations of the interior and ornamentation of the architecture, atmosphere and settings; folk customs encompass native people's collection such as carvings, paintings, folk tales, traditional apparatus which are still used in everyday life (Yi et al., 2018). Authenticity also significantly increases the attribute of tourism that will escalate an excursionist' satisfaction and perceived value (Lu et al., 2015), as well as indicating by being the crucial factor in influencing the overall excursionist's evaluation and positively influence loyalty (Shen, Guo and $\mathrm{Wu}, 2014$ ). Thus, it is hypothesised that authenticity has a significant positive effect on satisfaction and destination loyalty.

\section{Safety of Destination (SD)}

Numerous researchers have claimed on the idea of safety and have classified risks as accidents, natural disasters, terrorism, health issues, crime and violence, and presence of undocumented immigrants that will affect the performance of tourism (Kordić, Živković, Stanković \& Gajić, 2015). Hence, an excursionist's safety is an important factor that causes a global menace for sustainable tourism (Lai, Hitchcock, Lu \& Liu, 2018). Therefore, a destination has to be assured that it is safe to be visited, otherwise perceived risk or insecurity may cause the excursionist not to visit the tourist destination (Simpson et al., 2016).

According to Kordić et al. (2015), the most common accidents that happen to an excursionist are traffic accidents. Furthermore, sicknesses such as cholera, malaria, AIDS and as well as unsafe drinking water are threats for excursionist as the country's poverty unable to adequately safeguard the health of its citizen. Currently, it has also become a trend for terrorists to target excursionists and tourist facilities by purpose has caused distress among excursionists (Kordić et al., 2015). Foreign excursionists, particularly females are also at risk of becoming a crime victim, especially burglary that happens in the hotel or lodging (Millar, Collins \& Jones, 2017) as they are most likely to be unfamiliar with local legislation and procedures making them to be a target of crime (Lai et al., 2018). According to Rindrasih (2018), it is explained in Maslow's Theory that higher needs can never be satisfied unless safety and security is fulfilled. Hence, safety and 
Tourism and Sustainable Development Review Journal (TSDR), Vol. 2 (1), 01-18

Determinants of Excursionists' Satisfaction and Loyalty Towards Architectural Tourism in Ipoh Township, Malaysia

Anna Manisha Rames, Tan Gek Siang, Yeo Sook Fern

security should be prioritised to avoid negative word-of-mouth. Thus, it is hypothesised that safety of destination has a significant positive effect on satisfaction and destination loyalty.

\section{Cultural Differences (CD)}

Cultural and historic attraction can be defined as the creativity, civilisations and practice identified in a specific community and nation (Khuong \& Nguyen, 2017) or even as a conventional concept and custom deep-rooted in the diverse experiences that are significant in the community (Swanson \& DeVereaux, 2017). Symbols, rituals, values, heroes and practices are ways of cultural differences being performed (Albu, 2015). According to Albu (2015), symbol has a specific meaning that can be only recognised by those who are a part of the culture while rituals are shared actions that are fundamental in a culture. Hence, the completion has a value within itself and is focused on the culture that is of bipolar spirit with magnitude that is positive and negative (Albu, 2015). Heroes are individuals who are given the qualities in veneration to a culture and finally, practices are included of signs and ceremony that are observable and the cultural reputation remains imperceptible and depends on how these are concentrated within the circle.

Cultural charms are also essential features that motivate an excursionist to go on a trip (Vinh, 2013). The rare features of individual and collectivistic culture have a strong influence on individual's behaviour and psychology (Park, Kim \& O'Neill, 2014). According to Kani, Aziz, Sambasivan \& Bojei (2017), there is a significant effect of cultural standards on destination image and that cultural differences affect destination image which has a precise effect on an excursionist's conduct. Thus, it is hypothesised that cultural differences have a significant positive effect on satisfaction and destination loyalty.

\section{Satisfaction (ST)}

Satisfaction is a subjective assessment of an action or experience (Wu \& Zheng, 2014). However, satisfaction can also be defined as the level of positive feeling that is activated from the experience during an excursion (Jamaludin et al., 2012) and may even apply to the denouement of an excursionist's evaluation and comparison of the performance of the product or services is observed (Sangpikul, 2017). Abdullah \& Lui (2018) also defined satisfaction as a pragmatic perception or a feeling that is established or gained by contributing in leisure events and is expressed as the level of contentment obtained from that involvement.

Satisfaction is categorised with two common natures, that is transaction-specific and overall, in which transaction-specific satisfaction produced instantly after the visit, that takes place during the post - visit stage, whereby overall satisfaction is the fundamental of every encounter of destinations by evaluating the choices of past visits (Kim \& Thapa, 2018). Above all, satisfaction can also be measured using the "expectation met" model that weighs the elements through attribute specific precedence and determine if one's satisfaction assistant with one's willingness to revisit a tourist destination (Vinh, 2013).

Satisfaction also acts as an evaluation medium to assess the excursion experience, at the same time resulting a major impact on choosing a tourist destination, using a product or receiving a service and as well as the intention to revisit the destination (Lu et al., 2015). The excursionist also analyses his or her satisfaction by analysing the performance of the tourist destination with 
Tourism and Sustainable Development Review Journal (TSDR), Vol. 2 (1), 01-18 Determinants of Excursionists' Satisfaction and Loyalty Towards Architectural Tourism in Ipoh Township, Malaysia

Anna Manisha Rames, Tan Gek Siang, Yeo Sook Fern

the information received by him or her through word-of-mouth and promotions (Jamaludin et al., 2012). Excursionists' satisfaction is essential to be monitored by tourism authorities by obtaining responses and detecting the reasons of which cause discomforts as these reasons will cause a negative impact in the future visits (Sangpikul, 2017). The service quality also develops satisfaction in excursionists through a long-range relationship which results in destination loyalty (Bazneshin, Hosseini \& Azeri, 2015) which is essential for the overall level of economy (Vinh, 2013).

\section{Destination Loyalty (DL)}

According to Frangos et al. (2015), "loyalty is defined as a deeply held commitment to repurchase or re-patronise a preferred product or service consistently in the future, thereby causing repetitive same-brand or same-brand-set purchasing, despite marketing efforts to cause switching behaviour". Destination loyalty is in relative to the intention or desire to repeat the visit to the exact same tourist destination and having the intention in recommending the destination to others (Albaity \& Melhem, 2017). Loyalty can be categorised as behavioural and attitudinal, whereby behavioural loyalty will be reflected when an excursionist revisits a destination, meanwhile, attitudinal loyalty will be the effort hold on by the excursionist to recommend to their social circle by sharing their experiences by a positive word-of- mouth, that is also commonly known as post visit response, in which the personal attitude and emotion that reflects to destination loyalty (Almeida-Santana \& Moreno-Gil, 2017). Furthermore, when an excursionist intended to visit the same tourist destination again and keen to recommend the destination to others, it is denoted that the excursionist is loyal to the destination (Sangpikul, 2017; Khuong \& Nguyen, 2017). Loyalty to a tourist destination can also be described as the firmness of relationship between the attitude of an individual and to repeat visit that comes from being contented with a destination and compliant to offer continual business (Wu \& Zheng, 2014).

Cossío-Silva, Revilla-Camacho \& Vega-Vázquez (2018) said that loyalty will be attained when the destination outperforms an excursionist's hopes by providing an experience which is exclusive and engaging. Almeida-Santana \& Moreno-Gil (2018) also mentioned that horizontal loyalty approach is evident when an excursionist portrays loyalty to a different destination within the same level in the tourism framework. As it happens, it is said that an excursionist projects loyalty at a time towards multiple destinations. There are two classifications for loyalty, which are the attitude of excursionist to repurchase and secondly, the tendency of excursionist towards destination (Cossío-Silva, Revilla-Camacho \& Vega-Vázquez, 2018). Albaity \& Melhem (2017) also measured destination loyalty with the number of days of stay that subsequently measure the experience obtained by excursionists is much greater as the days increase due to the reverberation on accommodation, attraction, transportation, commerce and food in general. Therefore, destination loyalty is the result of attachment that was established by the excursionist which is caused by fulfilling a specific goal for its symbolic meaning that had resulted in attachment (Kani, et al., 2017).

\section{RESEARCH METHOD}

In studying the determinants of excursionists' satisfaction and destination loyalty towards architectural tourism destination in Ipoh Township, descriptive research design was applied as the researchers acknowledged the problem situation at hand. Mirrored by the downturn of the national 
tourism sector, the tourism performance in Perak is deteriorating in recent years as domestic tourists are shifting their preference of travel destination to other states and cities in Malaysia (Department of Statistics Malaysia, 2019). This study is classified as a descriptive research as it based on a research framework to test research hypotheses using primary data sources collected through a survey. Figure 1 illustrates the research framework of this study. Four variables namely Destination Image, Authenticity, Safety of Destination and Cultural Differences are postulated as the direct determinants of excursionists' satisfaction and destination loyalty toward the architectural tourism destination in Ipoh Township. A total of eight hypotheses are developed.

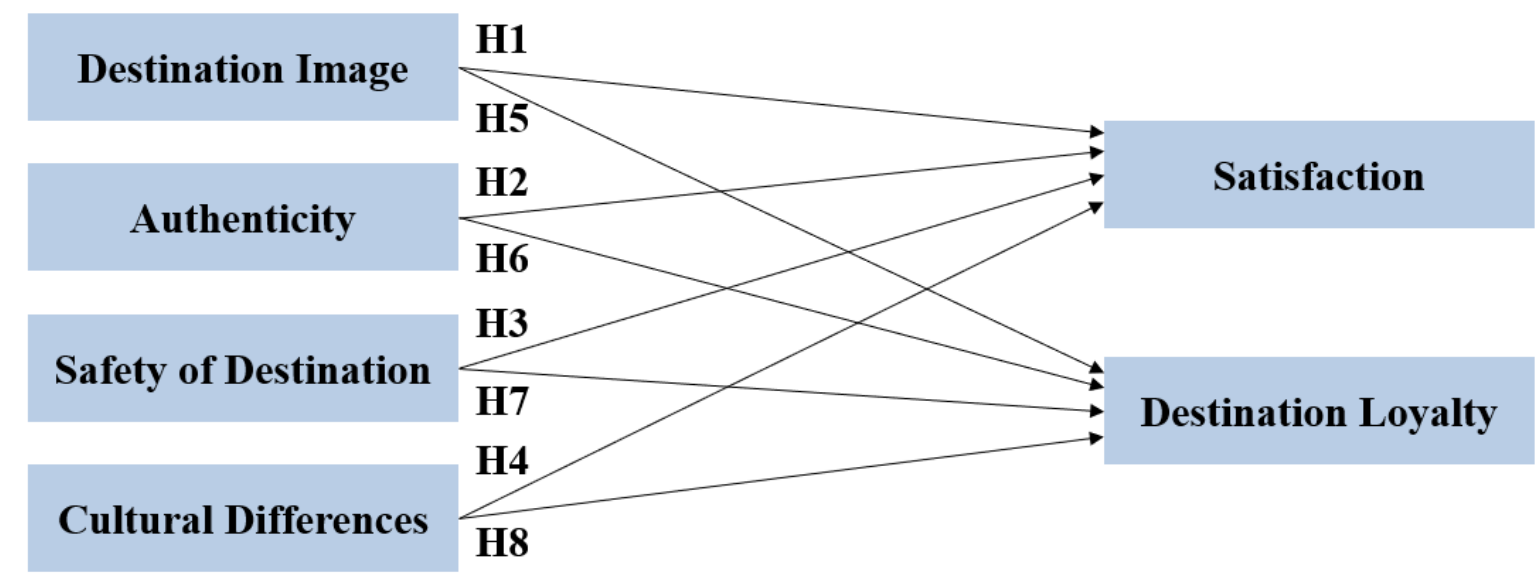

H1: Destination image has a significant positive effect on satisfaction.

$\mathrm{H} 2$ : Authenticity has a significant positive effect on satisfaction.

H3: Safety of Destination image has a significant positive effect on satisfaction.

H4: Cultural differences has a significant positive effect on satisfaction.

H5: Destination image has a significant positive effect on destination loyalty.

H6: Authenticity has a significant positive effect on destination loyalty.

H7: Safety of Destination image has a significant positive effect on destination loyalty.

H8: Cultural differences has a significant positive effect on destination loyalty.

Figure 1: Research Framework

Self-administered questionnaire was developed. Part A seeks to collect respondents' demographic information such as age, gender, nationality, marital status and occupation. Part B seeks to understand respondents' travel behaviour such as travel frequency, travel purpose, travel preference and source of travel information. Part C aims to gather respondents' level of agreement pertaining to the proposed determinants of excursionists' satisfaction and destination loyalty toward the architectural tourism destination in Ipoh Township, namely Destination Image (seven items), Authenticity (six items), Safety of Destination (six items), Cultural Differences (six items), Satisfaction (six items) and Destination Loyalty (six items). All items are measured using five-point Likert scale ranging from $1=$ Strongly Disagree to $5=$ Strongly Disagree. Before data collection, a content validity was conducted among subject matter experts to ensure clarity and relevance of the survey instruments using four-point Likert scale ranging from $1=$ Very Unclear to $4=$ Very Clear (for Degree of Clarity) and $1=$ Very Irrelevant to $4=$ Very Relevant (for Degree of Relevance). 
The survey was conducted from October to November 2019. 250 excursionists' who visited the architectural tourism destinations in Ipoh Township were randomly selected using convenience sampling technique. The architectural tourism destinations identified as location of data collection in Ipoh Township are Ipoh Railway Station, Majestic Station Hotel, Ipoh High Court, Han Chin Pet Soo, Ipoh Town Hall / Old Post Office, Darul Ridzuan Museum, Birch Memorial Clock Tower, Royal Ipoh Club, Ipoh State Museum and St. John's Anglican Church. Responses from the survey were first screened to avoid missing values before being analysed using the Statistical Package for Social Sciences software (SPSS 27.0). Descriptive analysis, normality test, reliability test and multiple linear regression analysis was conducted.

\section{FINDINGS AND DISCUSSION}

Consistent with Domestic Tourism Survey (Department of Statistics Malaysia, 2019), 85.2\% of the respondents are 55 years old and below, with 16-25 years old (24.0\%) dominating other age groups. There are more male respondents (54.0\%) than female respondents (46.0\%) in this study. Consistent with Department of Statistics Malaysia (2019) and Tourism Malaysia (2019) with regard to nationality of tourists, $86.8 \%$ of the respondents are locals. In this study, majority of the respondents are married (48.8\%). While most of the respondents are employed (56.4\%), one-fifth of the respondents are students (21.2\%). Table 1 shows the respondent's demographic profile.

Table 1: Respondents' Demographic Profile

\begin{tabular}{|c|c|c|c|c|c|}
\hline $\begin{array}{l}\text { Demographic } \\
\text { Profile }\end{array}$ & $\begin{array}{c}\text { Frequency } \\
\text { (n) }\end{array}$ & $\begin{array}{c}\text { Percentage } \\
(\%)\end{array}$ & $\begin{array}{c}\text { Demographic } \\
\text { Profile }\end{array}$ & $\begin{array}{c}\text { Frequency } \\
\text { (n) }\end{array}$ & $\begin{array}{c}\text { Percentage } \\
(\%)\end{array}$ \\
\hline Age & & & Marital Status & & \\
\hline $\begin{array}{l}\text { 16-25 years } \\
\text { old }\end{array}$ & 60 & 24.0 & Single & 94 & 37.6 \\
\hline $\begin{array}{l}\text { 26-35 years } \\
\text { old }\end{array}$ & 55 & 22.0 & Married & 122 & 48.8 \\
\hline $\begin{array}{l}36-45 \text { years } \\
\text { old }\end{array}$ & 58 & 23.2 & Divorced/Separated & 24 & 9.6 \\
\hline $\begin{array}{l}46-55 \text { years } \\
\text { old }\end{array}$ & 40 & 16.0 & Widowed & 10 & 4.0 \\
\hline $\begin{array}{l}\text { 56-65 years } \\
\text { old }\end{array}$ & 25 & 10.0 & & & \\
\hline \multirow[t]{3}{*}{$>65$ years old } & 12 & 4.8 & & & \\
\hline & & & Occupation & & \\
\hline & & & Full-time employed & 97 & 38.8 \\
\hline Gender & & & Part-time employed & 10 & 4.0 \\
\hline Male & 135 & 54.0 & Self-employed & 34 & 13.6 \\
\hline \multirow[t]{2}{*}{ Female } & 115 & 46.0 & Unemployed & 13 & 5.2 \\
\hline & & & Homemaker & 22 & 8.8 \\
\hline Nationality & & & Student & 53 & 21.2 \\
\hline Local & 217 & 86.8 & Retired & 21 & 8.4 \\
\hline International & 33 & 13.2 & & & \\
\hline
\end{tabular}


Majority of the respondents in this study travel once in a year (39.6\%). Consistent with Domestic Tourism Survey (Department of Statistics Malaysia, 2019), the top three travel purposes among the respondents are vacation (67.2\%), visiting relatives and friends (37.6\%) and shopping $(21.2 \%)$. In addition, most of the respondents prefer to travel with their family and friends $(76.8 \%)$. Social media $(62.4 \%)$ is the mostly referred source of travel information among the respondents, followed by word of mouth (33.2\%). Table 2 shows the respondents' travel experience.

Table 2: Respondents' Travel Experience

\begin{tabular}{|c|c|c|c|c|c|}
\hline $\begin{array}{c}\text { Travel } \\
\text { Behaviour }\end{array}$ & $\begin{array}{c}\text { Frequency } \\
\text { (n) }\end{array}$ & $\begin{array}{c}\text { Percentage } \\
(\%)\end{array}$ & $\begin{array}{c}\text { Travel } \\
\text { Behaviour }\end{array}$ & $\begin{array}{c}\text { Frequency } \\
\text { (n) }\end{array}$ & $\begin{array}{c}\text { Percentage } \\
(\%)\end{array}$ \\
\hline Travel Frequency & & & \multicolumn{3}{|c|}{ Travel Preference } \\
\hline Once a month & 20 & 8.0 & Family or friends & 192 & 76.8 \\
\hline $\begin{array}{l}\text { Once in } 3 \\
\text { months }\end{array}$ & 26 & 10.4 & Alone & 58 & 23.2 \\
\hline $\begin{array}{l}\text { Once in } 6 \\
\text { months }\end{array}$ & 67 & 26.8 & & & \\
\hline Once a year & 99 & 39.6 & \multicolumn{3}{|c|}{ Source of Information } \\
\hline $\begin{array}{l}\text { Once in few } \\
\text { vears }\end{array}$ & 38 & 15.2 & Tourism Office & 32 & 12.8 \\
\hline & & & Travel agents & 26 & 10.4 \\
\hline Travel Purpose & & & Travel magazine & 40 & 16.0 \\
\hline Visiting people & 94 & 37.6 & Newspapers & 37 & 14.8 \\
\hline Work / Job & 25 & 10.0 & Brochures & 30 & 12.0 \\
\hline Convention & 6 & 2.4 & Travel websites & 55 & 22.0 \\
\hline Education & 6 & 2.4 & Social Media & 156 & 62.4 \\
\hline Shopping & 53 & 21.2 & Television & 55 & 22.0 \\
\hline Vacation & 168 & 67.2 & Radio & 28 & 11.2 \\
\hline Business & 15 & 6.0 & Past Knowledge & 44 & 17.6 \\
\hline Sport & 7 & 2.8 & Word of mouth & 83 & 33.2 \\
\hline
\end{tabular}

Based on a five-point Likert scale ranging from $1=$ Strongly Disagree to $5=$ Strongly Agree, all variables recorded a relatively high mean value ranging from 3.65 to 3.83. Furthermore, the collected data is deemed to be normally distributed. Skewness and kurtosis statistics of the variables are well within the tolerable range of -0.412 to -0.298 and -0.396 to 0.010 , respectively. Skewness and kurtosis statistics beyond the range of \pm 3 and \pm 10 respectively suggest that data is not normally distributed. In addition, the Cronbach's Alpha statistics of all variables which range from 0.753 to 0.821 are considered to achieve the critical value of greater than 0.75 and reflected a good internal reliability of the data (Nunnally, 1978; Peterson, 1994; Sekaran, 2000; Sekaran \& Bougie, 2009). Table 3 to 8 shows the mean, normality and reliability of items measuring the variables of the study. 
Tourism and Sustainable Development Review Journal (TSDR), Vol. 2 (1), 01-18

Determinants of Excursionists' Satisfaction and Loyalty Towards Architectural Tourism in Ipoh Township, Malaysia

Anna Manisha Rames, Tan Gek Siang, Yeo Sook Fern

Table 3: Mean, Normality and Reliability of Items Measuring Destination Image (DI)

\begin{tabular}{llcccc}
\hline \multicolumn{1}{c}{ Item } & Mean & Skewness & Kurtosis & $\begin{array}{c}\text { Reliability } \\
\text { (Cronbach } \\
\text { Alpha) }\end{array}$ \\
\cline { 3 - 4 } & & 3.88 & -0.660 & 0.769 & \\
\hline DI1 & $\begin{array}{l}\text { The destination has a beautiful } \\
\text { scenery and natural attractions. }\end{array}$ & 3.73 & -0.221 & 0.072 & \\
DI2 & $\begin{array}{l}\text { The destination provides good } \\
\text { value for money. }\end{array}$ & & & & \\
DI3 & $\begin{array}{l}\text { I enjoyed the style of buildings at } \\
\text { the destination. }\end{array}$ & 3.90 & -0.150 & -0.707 & \\
DI4 & $\begin{array}{l}\text { The destination has a mystical } \\
\text { atmosphere. }\end{array}$ & 3.68 & -0.363 & -0.133 & \multirow{2}{*}{0.770} \\
DI5 & $\begin{array}{l}\text { The destination is a place with } \\
\text { historic and heritage wealth. }\end{array}$ & 3.80 & -0.317 & -0.294 & \\
DI6 & $\begin{array}{l}\text { Ipoh is a progressive township. } \\
\text { The destination provides local } \\
\text { DI7 }\end{array}$ & 3.94 & -0.516 & 0.005 & \\
$\quad \begin{array}{l}\text { specialities such as unique } \\
\text { souvenirs and mementos. }\end{array}$ & 3.73 & -0.609 & 0.353 & \\
\hline Average & 3.81 & -0.405 & 0.010 & \\
\hline
\end{tabular}

Table 4: Mean, Normality and Reliability of Items Measuring Authenticity (AT)

\begin{tabular}{|c|c|c|c|c|c|}
\hline \multirow{2}{*}{\multicolumn{2}{|c|}{ Item }} & \multirow[b]{2}{*}{$\begin{array}{l}\text { Level of } \\
\text { Agreement }\end{array}$} & \multicolumn{2}{|c|}{ Normality } & \multirow{2}{*}{$\begin{array}{c}\text { Reliability } \\
\text { (Cronbach } \\
\text { Alpha) }\end{array}$} \\
\hline & & & Skewness & Kurtosis & \\
\hline AT1 & $\begin{array}{l}\text { The originality of the architecture } \\
\text { is preserved till date. }\end{array}$ & 3.89 & -0.179 & -0.669 & \multirow{7}{*}{0.819} \\
\hline AT2 & $\begin{array}{l}\text { The mixture of cultures are } \\
\text { reflected } \\
\text { on the architecture. }\end{array}$ & 3.84 & -0.350 & -0.302 & \\
\hline AT3 & $\begin{array}{l}\text { The influence of colonial era is } \\
\text { exhibited on the architecture. }\end{array}$ & 3.88 & -0.288 & -0.332 & \\
\hline AT4 & $\begin{array}{l}\text { The destination portrays ancient } \\
\text { lifestyle and customs. }\end{array}$ & 3.85 & -0.319 & -0.515 & \\
\hline AT5 & $\begin{array}{l}\text { The destination arouses feelings } \\
\text { of authentic history and culture. }\end{array}$ & 3.73 & -0.302 & -0.504 & \\
\hline AT6 & $\begin{array}{l}\text { The overall appearance and } \\
\text { impression of the destination } \\
\text { inspires me. }\end{array}$ & 3.80 & -0.463 & -0.055 & \\
\hline \multicolumn{2}{|c|}{ Average } & 3.83 & -0.317 & -0.396 & \\
\hline
\end{tabular}


Tourism and Sustainable Development Review Journal (TSDR), Vol. 2 (1), 01-18

Determinants of Excursionists' Satisfaction and Loyalty Towards Architectural Tourism in Ipoh Township, Malaysia

Anna Manisha Rames, Tan Gek Siang, Yeo Sook Fern

Table 5: Mean, Normality and Reliability of Items Measuring Safety of Destination (SD)

\begin{tabular}{|c|c|c|c|c|c|}
\hline & \multirow{2}{*}{ Item } & \multirow{2}{*}{$\begin{array}{c}\text { Level of } \\
\text { Agreement }\end{array}$} & \multicolumn{2}{|c|}{ Normality } & \multirow{2}{*}{$\begin{array}{c}\text { Reliability } \\
\text { (Cronbach } \\
\text { Alpha) }\end{array}$} \\
\hline & & & Slrewmecc & Kurtocic & \\
\hline SD1 & $\begin{array}{l}\text { The destination is safe for tourists } \\
\text { regardless of age and gender. }\end{array}$ & 3.96 & -0.186 & -0.738 & \\
\hline SD2 & $\begin{array}{l}\text { The locals strictly adhere to the } \\
\text { law set by the local government. }\end{array}$ & 3.77 & -0.256 & -0.378 & \\
\hline SD3 & $\begin{array}{l}\text { Accidents, crime and violence in } \\
\text { the township is low. }\end{array}$ & 3.60 & -0.266 & -0.174 & \\
\hline SD4 & $\begin{array}{l}\text { The political environment in the } \\
\text { township is stable. }\end{array}$ & 3.82 & -0.311 & -0.280 & 0.819 \\
\hline SD5 & $\begin{array}{l}\text { Healthy and hygienic foods are } \\
\text { widely available in the township. }\end{array}$ & 3.84 & -0.402 & 0.018 & \\
\hline SD6 & $\begin{array}{l}\text { The destination has high level of } \\
\text { cleanliness and sanitation. }\end{array}$ & 3.88 & -0.490 & 0.154 & \\
\hline \multicolumn{2}{|c|}{ Average } & 3.81 & -0.319 & -0.233 & \\
\hline
\end{tabular}

Table 6: Mean, Normality and Reliability of Items Measuring Cultural Differences (CD)

\begin{tabular}{llcccc}
\hline \multicolumn{1}{c}{ Item } & $\begin{array}{c}\text { Level of } \\
\text { Agreement }\end{array}$ & Skewness & Kurtosis & $\begin{array}{c}\text { Reliability } \\
\text { (Cronbach } \\
\text { Alpha) }\end{array}$ \\
CD1 & $\begin{array}{l}\text { I enjoyed exploring diverse } \\
\text { cultures in Ipoh township. }\end{array}$ & 3.85 & -0.336 & 0.053 & \\
CD2 & $\begin{array}{l}\text { I like to learn different cultures / } \\
\text { ways of life. }\end{array}$ & 3.83 & -0.527 & 0.499 \\
CD3 & $\begin{array}{l}\text { There are many cultural } \\
\text { attractions in Ipoh township. }\end{array}$ & 3.87 & -0.385 & 0.150 & \\
CD4 & $\begin{array}{l}\text { There are various cultural events } \\
\text { held at Ipoh township. }\end{array}$ & 3.72 & -0.441 & -0.115 & \multirow{2}{*}{0.753} \\
CD5 & $\begin{array}{l}\text { I enjoy watching the arts and } \\
\text { cultural performances by the } \\
\text { locals. }\end{array}$ & 3.76 & -0.300 & -0.294 & \\
CD6 & $\begin{array}{l}\text { I have high level of acceptance on } \\
\text { other cultures. }\end{array}$ & 3.92 & -0.482 & -0.260 & \\
\hline Average & 3.83 & -0.412 & 0.006 & \\
\hline
\end{tabular}


Tourism and Sustainable Development Review Journal (TSDR), Vol. 2 (1), 01-18

Determinants of Excursionists' Satisfaction and Loyalty Towards Architectural Tourism in Ipoh Township, Malaysia

Anna Manisha Rames, Tan Gek Siang, Yeo Sook Fern

Table 7: Mean, Normality and Reliability of Items Measuring Satisfaction (ST)

\begin{tabular}{|c|c|c|c|c|c|}
\hline \multirow{2}{*}{\multicolumn{2}{|c|}{ Item }} & \multirow{2}{*}{$\begin{array}{c}\text { Level of } \\
\text { Agreement }\end{array}$} & \multicolumn{2}{|c|}{ Normality } & \multirow{2}{*}{$\begin{array}{c}\text { Reliability } \\
\text { (Cronbach } \\
\text { Alpha) }\end{array}$} \\
\hline & & & Skewness & Kurtosis & \\
\hline ST1 & $\begin{array}{l}\text { I have gained knowledge after } \\
\text { visiting the destination. }\end{array}$ & 3.92 & -0.122 & -0.705 & \multirow{7}{*}{0.821} \\
\hline ST2 & $\begin{array}{l}\text { Now, I have a better } \\
\text { understanding about the history } \\
\text { of the destination. }\end{array}$ & 3.74 & -0.347 & 0.318 & \\
\hline ST3 & $\begin{array}{l}\text { Every Ringgit spent at the } \\
\text { destination is worthy. }\end{array}$ & 3.78 & -0.362 & 0.006 & \\
\hline ST4 & $\begin{array}{l}\text { I am very pleased that I decided to } \\
\text { visit the destination. }\end{array}$ & 3.81 & -0.519 & 0.186 & \\
\hline ST5 & The visit was a good experience. & 2.93 & -0.359 & -0.350 & \\
\hline ST6 & $\begin{array}{l}\text { The destination exceeds my } \\
\text { expectations. }\end{array}$ & 3.70 & -0.264 & 0.094 & \\
\hline Aver & & 3.65 & -0.329 & -0.075 & \\
\hline
\end{tabular}

Table 8: Mean, Normality and Reliability of Items Measuring Destination Loyalty (DL)

\begin{tabular}{llcccc}
\hline \multicolumn{1}{c}{ Item } & \multirow{2}{*}{$\begin{array}{c}\text { Level of } \\
\text { Agreement }\end{array}$} & Skewness & Kurtosis & $\begin{array}{c}\text { Reliability } \\
\text { (Cronbach } \\
\text { Alpha) }\end{array}$ \\
\cline { 4 - 5 } DL1 & $\begin{array}{l}\text { There is a high likelihood to } \\
\text { revisit the destination in the }\end{array}$ & 3.79 & -0.270 & -0.205 & \\
future. & & & & \\
DL2 & $\begin{array}{l}\text { I will definitely revisit the } \\
\text { destination in the future. }\end{array}$ & 3.70 & -0.121 & -0.471 & \\
DL3 & $\begin{array}{l}\text { The destination will be my first } \\
\text { choice to revisit in the future. }\end{array}$ & 3.69 & -0.348 & -0.085 & \\
DL4 $\begin{array}{l}\text { I will give positive feedback on } \\
\text { the destination. }\end{array}$ & 3.85 & -0.415 & 0.056 & 0.807 \\
DL5 & $\begin{array}{l}\text { I will recommend the destination } \\
\text { to others. }\end{array}$ & 3.79 & -0.279 & -0.291 & \\
DL6 & $\begin{array}{l}\text { The destination is a better place to } \\
\text { visit compared to others. }\end{array}$ & 3.79 & -0.356 & -0.271 & \\
\hline Average & 3.77 & -0.298 & -0.211 & \\
\hline
\end{tabular}

Multiple linear regression analysis was conducted to determine the linear relationship between the independent variables and Satisfaction. Table 9 reports the regression analysis of variables determining Satisfaction. The Model Summary table reported the adjusted R2 was 0.486, indicating that $48.6 \%$ of the variation in Satisfaction can be accounted by the variation in Destination Image, Authenticity, Safety of Destination and Cultural Differences. The ANOVA table 12 
Tourism and Sustainable Development Review Journal (TSDR), Vol. 2 (1), 01-18

Determinants of Excursionists' Satisfaction and Loyalty Towards Architectural Tourism in Ipoh Township, Malaysia

Anna Manisha Rames, Tan Gek Siang, Yeo Sook Fern

indicated that at least one independent variable has a significant contribution to the model. The Coefficients table confirmed that all the independent variables were significantly associated with the dependent variable $(\mathrm{p}<0.05)$. Cultural Differences was found to be the strongest determinant of Satisfaction with the largest $\beta$ value (0.359). The regression model can be written as Satisfaction $=0.597+0.110$ Destination Image +0.167 Authenticity +0.180 Safety of Destination +0.359 Cultural Differences. The first research objective (To examine the determinants of excursionists' Satisfaction towards architectural tourism at Ipoh Township) is achieved. Table 11 shows that Hypothesis 1 to 4 are supported.

Table 9: Regression Analysis of Variables Determining Satisfaction (ST)

\begin{tabular}{|c|c|c|c|c|c|}
\hline \multicolumn{6}{|c|}{ Model Summary } \\
\hline Model & $\mathrm{R}$ & R Square & $\begin{array}{l}\text { Adjusted } \\
\text { R Square }\end{array}$ & \multicolumn{2}{|c|}{$\begin{array}{l}\text { Std. Error of } \\
\text { the Estimate }\end{array}$} \\
\hline 1 & 0.697 & 0.486 & 0.478 & 0.4 & \\
\hline \multicolumn{6}{|c|}{ ANOVA } \\
\hline Model & $\begin{array}{l}\text { Sum of } \\
\text { Squares }\end{array}$ & $\mathrm{df}$ & Mean Square & $\mathrm{F}$ & Sig. \\
\hline Regression & 42.463 & 4 & 10.616 & & \\
\hline Residual & 44.826 & 245 & 0.183 & 58.022 & 0.000 \\
\hline Total & 87.289 & 249 & & & \\
\hline \multicolumn{6}{|c|}{ Coefficients } \\
\hline \multirow{2}{*}{ Model } & \multicolumn{2}{|c|}{$\begin{array}{c}\text { Unstandardised } \\
\text { Coefficients }\end{array}$} & $\begin{array}{c}\text { Standardised } \\
\text { Coefficient }\end{array}$ & \multirow{2}{*}{$\mathrm{t}$} & \multirow{2}{*}{ Sig. } \\
\hline & B & $\begin{array}{l}\text { Standard } \\
\text { Error }\end{array}$ & Beta & & \\
\hline Constant & 0.597 & 0.221 & & 2.706 & 0.007 \\
\hline Destination Image & 0.120 & 0.065 & 0.110 & 1.862 & 0.048 \\
\hline Authenticity & 0.161 & 0.064 & 0.167 & 2.496 & 0.013 \\
\hline Safety of Destination & 0.177 & 0.067 & 0.180 & 2.665 & 0.008 \\
\hline Cultural Differences & 0.383 & 0.072 & 0.359 & 5.358 & 0.000 \\
\hline
\end{tabular}

Next, multiple linear regression analysis was conducted to determine the linear relationship between the independent variables and Destination Loyalty. Table 10 reports the regression analysis of variables determining Destination Loyalty. The Model Summary table reported that the adjusted R2 was 0.494 , indicating that $49.4 \%$ of the variation in Destination Loyalty can be accounted by the variation in Destination Image, Authenticity, Safety of Destination and Cultural Differences. The ANOVA table indicated that at least one independent variable has a significant contribution to the model. The Coefficients table confirmed that all the independent variables were significantly associated with the dependent variable $(p<0.05)$. Again, Cultural Differences was found to be the strongest determinant of Destination Loyalty with the largest $\beta$ value (0.280). The regression model is written as Destination Loyalty $=0.567+0.141$ Destination Image +0.231 Authenticity +0.179 Safety of Destination +0.280 Cultural Differences. The second research objective (To examine the determinants of excursionists' Destination Loyalty towards 
Tourism and Sustainable Development Review Journal (TSDR), Vol. 2 (1), 01-18

Determinants of Excursionists' Satisfaction and Loyalty Towards Architectural Tourism in Ipoh Township, Malaysia

Anna Manisha Rames, Tan Gek Siang, Yeo Sook Fern

architectural tourism at Ipoh Township) is achieved. Table 11 shows that Hypothesis 5 to 8 are supported.

Table 10: Regression Analysis of Variables Determining Destination Loyalty (DL)

\begin{tabular}{|c|c|c|c|c|c|}
\hline \multicolumn{6}{|c|}{ Model Summary } \\
\hline Model & $\mathrm{R}$ & R Square & $\begin{array}{l}\text { Adjusted } \\
\text { R Square }\end{array}$ & \multicolumn{2}{|c|}{$\begin{array}{l}\text { Std. Error of } \\
\text { the Estimate }\end{array}$} \\
\hline 1 & 0.703 & 0.494 & 0.485 & \multicolumn{2}{|c|}{0.41691} \\
\hline \multicolumn{6}{|c|}{ ANOVA } \\
\hline Model & $\begin{array}{r}\text { Sum of } \\
\text { Squares }\end{array}$ & $\mathrm{df}$ & Mean Square & $\mathrm{F}$ & Sig. \\
\hline Regression & 41.515 & 4 & 10.379 & & \\
\hline Residual & 42.585 & 245 & 0.174 & 59.712 & 0.000 \\
\hline Total & 84.100 & 249 & & & \\
\hline \multicolumn{6}{|c|}{ Coefficients } \\
\hline \multirow{2}{*}{ Model } & \multicolumn{2}{|c|}{$\begin{array}{l}\text { Unstandardised } \\
\text { Coefficients }\end{array}$} & $\begin{array}{c}\text { Standardised } \\
\text { Coefficient }\end{array}$ & \multirow{2}{*}{$\mathrm{t}$} & \multirow{2}{*}{ Sig. } \\
\hline & B & $\begin{array}{c}\text { Standard } \\
\text { Error }\end{array}$ & Beta & & \\
\hline Constant & 0.567 & 0.215 & & 2.636 & 0.009 \\
\hline Destination Image & 0.152 & 0.063 & 0.141 & 1.413 & 0.017 \\
\hline Authenticity & 0.219 & 0.063 & 0.231 & 3.492 & 0.001 \\
\hline Safety of Destination & 0.174 & 0.065 & 0.179 & 2.677 & 0.008 \\
\hline Cultural Differences & 0.293 & 0.070 & 0.280 & 4.201 & 0.000 \\
\hline
\end{tabular}

Table 11: Hypothesis Test Outcome

\begin{tabular}{lc}
\hline \multicolumn{1}{c}{ Hypotheses } & $\begin{array}{c}\text { Test } \\
\text { Outcome }\end{array}$ \\
\hline H1: Destination image has a significant positive effect on satisfaction. & Supported \\
H2: Authenticity has a significant positive effect on satisfaction. & Supported \\
H3: Safety of Destination image has a significant positive effect on satisfaction. & Supported \\
H4: Cultural differences has a significant positive effect on satisfaction. & Supported \\
H5: Destination image has a significant positive effect on destination loyalty. & Supported \\
H6: Authenticity has a significant positive effect on destination loyalty. & Supported \\
H7: Safety of Destination image has a significant positive effect on destination & Supported \\
$\quad$ loyalty. & \\
H8: Cultural differences has a significant positive effect on destination loyalty. & Supported \\
\hline
\end{tabular}

\section{CONCLUSION \& FURTHER RESEARCH}

The findings of this study provide important managerial implications to the tourism stakeholders, namely the tourism authorities, management of architectural tourism destination, associated tourism businesses and the local community. The tourism stakeholders should protect, preserve and conserve cultural diversity of the Ipoh Township as Cultural Diversity is found to be the strongest determinant of visitors' satisfaction and destination loyalty toward the architectural 14 
Tourism and Sustainable Development Review Journal (TSDR), Vol. 2 (1), 01-18 Determinants of Excursionists' Satisfaction and Loyalty Towards Architectural Tourism in Ipoh Township, Malaysia

Anna Manisha Rames, Tan Gek Siang, Yeo Sook Fern

tourism destination. According to the Department of Statistics Malaysia (2020), the Population and Housing Census 2010 reported that Perak is one of the states in Malaysia with a more balance ethnicity distribution such that the 2.3 million of entire state population comprises of $57.2 \%$ of Malay and other indigenous (Bumiputera), 30.3\% of Chinese, $12.3 \%$ of Indian and $0.2 \%$ of other ethnicity groups. The multi-ethnic society allows the people to freely practice different religions, rituals, traditions and customs. Such diverse cultural background can be seen from various old worship places, namely the 122-year-old Panglima Kinta Mosque, 100-year-old Perak Tong Cave Buddhist Temple, the 150-year-old Sri Maha Karumariamman Muneeswarar Hindu Temple, the 130-year-old St. Michael's Church, to name a few. In addition, the local tourism authorities should work closely with the local museums to showcase arts and live cultural performances to the visitors who love to explore and learn different cultures and ways of life of the local community.

Furthermore, in light of the National Heritage Act 2005 (Akta Warisan Kebangsaan 2005), the Department of National Heritage (Jabatan Warisan Negara) should work collaboratively with the local tourism authorities to preserve, conserve and manage both tangible and intangible cultural heritage assets of national importance. Such effort will preserve the originality of the architecture tourism destination to enhance tourists' experience of authentic history and culture of the Ipoh Township. Furthermore, the Ipoh City Council (Majlis Bandaraya Ipoh) should maintain the destination image of Ipoh as a progressive township through development planning and control, maintenance of street buildings and upgrading of public amenities. A distinctive destination image provides tourists good value of money for visiting the architectural tourism destination in Ipoh Township. Moreover, the municipal council should improve rubbish collection services and manage businesses and hawkers licensing to ensure architectural tourism destinations to comply with high standard of sanitation and hygiene level. Last but not least, the municipal council should work hand in hand with the Royal Malaysia Police (Polis Diraja Malaysia) and Road Transport Department Malaysia (Jabatan Pengangkutan Jalan) to improve road and traffic management in the township so that road accidents and crime rate can be reduced to improve destination's safety.

The current study encounters several limitations like many others. First, the findings are only geographically confined to the architectural tourism destinations in Ipoh Township. As a result, generalising the findings to other destinations is not feasible. Thus, future researchers are suggested to replicate this study in other architectural tourism destinations in Malaysia such as the UNESCO World Heritage Cities of Melaka and Georgetown, or other architectural tourism destinations in ASEAN region. Secondly, future researchers should examine other determinants of tourists' satisfaction and destination loyalty to improve the explanatory power of the underlying determinants in this study.

\section{ACKNOWLEDGMENT}

The authors would like to thank Multimedia University for rendering assistance and support in conducting this study through the providence of library resources and research facilities. The authors would also like to thank Research Synergy Foundation for providing a scholastic platform for the study to be presented in the 4th International Conference on Entrepreneurship Studies, Business, Economy, and Management Science (ESBEM) 2020 with publication opportunity. 


\section{REFERENCES}

Abdullah, S. I. N. W., \& Lui, E. (2018). Satisfaction Drivers and Revisit Intention of International Tourists in Malaysia. Journal of Tourism, Hospitality and Environment Management, 3(9), 1-13.

Albaity, M., \& Melhem, S. B. (2017). Novelty Seeking, Image, and Loyalty-The Mediating Role of Satisfaction and Moderating Role of Length of Stay: International Tourists' Perspective. Tourism Management Perspectives, 23, 30-37.

Albayrak, T., \& Caber, M. (2018). Examining the Relationship Between Tourist Motivation and Satisfaction by Two Competing Methods. Tourism Management, 69, 201-213.

Albu, C. E. (2015). Intercultural Communication Tourism. Cross-Cultural Management Journal, 18(1), 7-14.

Almeida-Santana, A., \& Moreno-Gil, S. (2017). New Trends in Information Search and Their Influence on Destination Loyalty: Digital Destinations and Relationship Marketing. Journal of Destination Marketing and Management, 6(2), 150-161.

Almeida-Santana, A., \& Moreno-Gil, S. (2018). Understanding Tourism Loyalty: Horizontal vs. Destination Loyalty. Tourism Management, 65, 245-255.

Bazneshin, S. D., Hosseini, S. B., \& Azeri, A. R. K. (2015). The Physical Variables of Tourist Areas to Increase the Tourists' Satisfaction Regarding the Sustainable Tourism Criteria: Case Study of Rudsar Villages, Sefidab in Rahim Abad. Procedia - Social and Behavioral Sciences, 201, 128-135.

Cossío-Silva, F.-J., Revilla-Camacho, M.-Á., \& Vega-Vázquez, M. (2018). The Tourist Loyalty Index: A New Indicator for Measuring Tourist Destination Loyalty? Journal of Innovation \& Knowledge, 4(2), 71-77.

Department of Statistic Malaysia. (2019). Domestic Tourism Survey 2018. Retrieved from https://www.dosm.gov.my/v1/index.php?r=column/cthemeByCat\&cat=320\&bul_id=cUJybTRyN WZYd05qY2xlSmJFQXhYdz09\&menu_id=b0pIV1E3RW40VWRTUkZocEhyZ1pLUT09

Frangos, C. C., Karapistolis, D., Stalidis, G., Constantinos, F., Sotiropoulos, I., \& Manolopoulos, I. (2015). Tourist Loyalty is All about Prices, Culture and the Sun: A Multinomial Logistic Regression of Tourists Visiting Athens. Procedia - Social and Behavioral Sciences, 175, 32-38.

Jamaludin, M., Johari, S., Aziz, A., Kayat, K., \& Yusof, A. R. M. (2012). Examining Structural Relationship Between Destination Image, Tourist Satisfaction and Destination Loyalty. International Journal of Independent Research and Studies, 1(3), 89-96.

Kani, Y., Aziz, Y. A., Sambasivan, M., \& Bojei, J. (2017). Antecedents and Outcomes of Destination Image of Malaysia. Journal of Hospitality and Tourism Management, 32, 89-98.

Khuong, M. N., \& Nguyen, P. A. (2017). Factors Affecting Tourist Destination Satisfaction and Return Intention - A Study in Ho Chi Minh City, Vietnam. Journal of Economics, Business and Management, 5(2), 95-102.

Kim, M., \& Thapa, B. (2018). The Influence of Self-Congruity, Perceived Value, and Satisfaction on Destination Loyalty: A Case Study of the Korean DMZ. Journal of Heritage Tourism, 13(3), 224236.

Kordić, N., Živković, R., Stanković, J., \& Gajić, J. (2015). Safety and Security as Factors of Tourism Destination Competitiveness. In Proceedings of the Singidunum International Tourism Conference - Sitcon 2015 (pp. 34-38). Belgrade, Serbia: Singidunum University. 
Lai, I. K. W., Hitchcock, M., Lu, D., \& Liu, Y. (2018). The Influence of Word of Mouth on Tourism Destination Choice: Tourist-Resident Relationship and Safety Perception Among Mainland Chinese Tourists Visiting Macau. Sustainability, 10(7), 2114.

Lee, T. R., Jiun S., Kuo, Y. H., \& Muhos, M. (2015). Applying Interpretive Structural Modeling to the Planning of a Sequence of Marketing Strategies: A Case Study of the Architectural Tourism in Taiwan. Asia Pacific Journal of Tourism Research, 20(10), 1132-1150.

Loi, L. T. I., So, A. S. I., Lo, I. S., \& Fong, L. H. N. (2017). Does the Quality of Tourist Shuttles Influence Revisit Intention Through Destination Image and Satisfaction? The Case of Macao. Journal of Hospitality and Tourism Management, 32, 115-123.

Lu, L., Chi, C. G., \& Liu, Y. (2015). Authenticity, Involvement, and Image: Evaluating Tourist Experiences at Historic Districts. Tourism Management, 50, 85-96.

Millar, M., Collins, M. and Jones, D. (2017). Exploring the Relationship between Destination Image, Aggressive Street Behavior, and Tourist Safety. Journal of Hospitality Marketing \& Management, 26(7), 735-751.

Nguyen, T. H. H., \& Cheung, C. (2016). Toward an Understanding of Tourists' Authentic Heritage Experiences: Evidence from Hong Kong. Journal of Travel and Tourism Marketing, 33(7), 999-1010.

Nunnally, J. C. (1970). Psychometric theory. (1st Ed.). New York: McGraw-Hill.

Park, S. G., Kim, K., \& O’Neill, M. (2014). Complaint Behavior Intentions and Expectation of Service Recovery in Individualistic and Collectivistic Cultures. International Journal of Culture, Tourism, and Hospitality Research, 8(3), 255-271.

Peterson, R. A. (1994). A meta-analysis of Cronbach's coefficient alpha. Journal of Consumer Research, 381-391.

Rindrasih, E. (2018). Tourists' Perceived Risk and Image of Destinations Prone toNatural Disasters: The Case of Bali and Yogyakarta, Indonesia. Jurnal Humaniora, 30(2), 192-203.

Sangpikul, A. (2017). A Study of Effects of European Tourists' Satisfaction on Destination Loyalty in Phuket, WMS Journal of Management, 6(1), 73-83.

Sekaran, U. (2000). Research methods for business: A skill building approach. (2nd Edition). New York: John Wiley \& Sons.

Sekaran, U. and Bougie, R. (2010). Research methods for business: A skill building approach. Wiley.

Shen, S., Guo, J., \& Wu, Y. (2014). Investigating the Structural Relationships among Authenticity, Loyalty, Involvement, and Attitude toward World Cultural Heritage Sites: An Empirical Study of Nanjing Xiaoling Tomb, China. Asia Pacific Journal of Tourism Research, 19(1), 103-121.

Simpson, J. J., Simpson, P. M., \& Cruz-Milán, O. (2016). Attitude Towards Immigrants and Security: Effects on Destination-Loyal Tourists. Tourism Management, 57, 373-386.

Souiden, N., Ladhari, R., \& Chiadmi, N. E. (2017). Destination Personality and Destination Image. Journal of Hospitality and Tourism Management, 32, 54-70.

Stylos, N., Bellou, V., Andronikidis, A., \& Vassiliadis, C. A. (2017). Linking the Dots Among Destination Images, Place Attachment, and Revisit Intentions: A study Among British and Russian Tourists. Tourism Management, 60, 15-29. 
Swanson, K. K., \& DeVereaux, C. (2017). A theoretical framework for sustaining culture: Culturally sustainable entrepreneurship. Annals of Tourism Research, 62, 78-88.

Thyne, M., \& Hede, A. M. (2016). Approaches to Managing Co-Production for the Co-Creation of Value in A Museum Setting: when authenticity matters. Journal of Marketing Management, 32(15-16), 1478-1493.

Vinh, N. Q. (2013). Destination Culture and Its Influence on Tourist Motivation and Tourist Satisfaction of Homestay Visit. Journal of The Faculty of Economics and Administration Sciences, 3(2), 199-222.

World Tourism Organisation. (2019). International Tourism Highlights 2019 Edition. Retrieved from https://www.e-unwto.org/doi/pdf/10.18111/9789284421152

Wu, S.-I., \& Zheng, Y.-H. (2014). The Influence of Tourism Image and Activities Appeal on Tourist Loyalty - A Study of Tainan City in Taiwan. Journal of Management and Strategy, 5(4), 121-135.

Yi, X., Fu, X., Yu, L., \& Jiang, L. (2018). Authenticity and Loyalty at Heritage Sites: The Moderation Effect of Postmodern Authenticity. Tourism Management, 67, 411-424. 